\title{
A Country Just for Liars: The Taciturn Truth of the Orthopsychic Eye
}

\section{DON KUNZE}

Penn State University

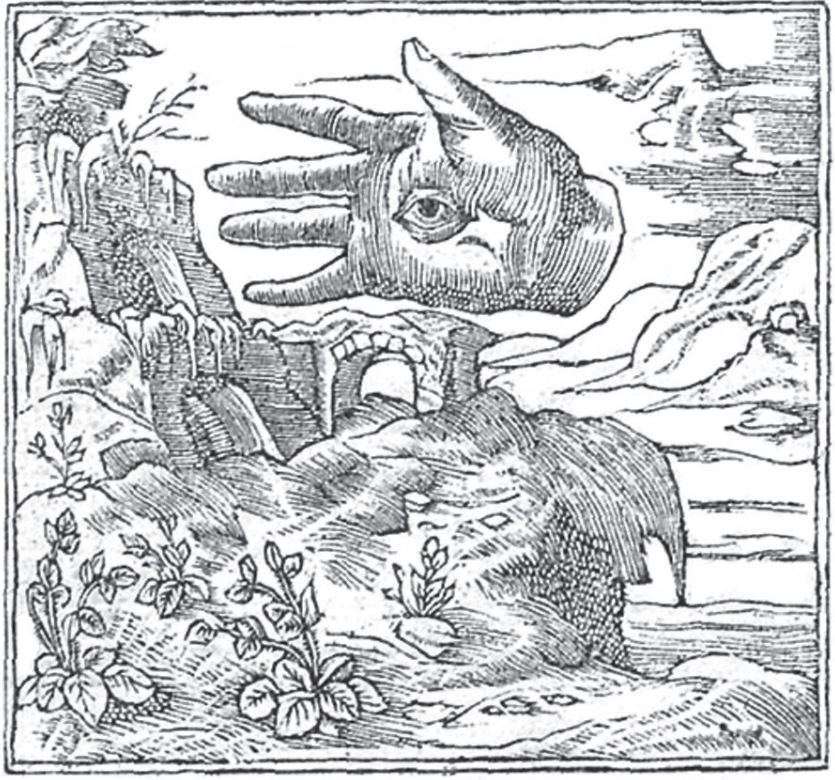

Figure 1. Alciati, Emblemata (Lyon: 1551), "Prudencia." "Sobriè vivendum: \& non timer credendum;" "We live: and (are) not afraid to believe."

purity of form; but in fact it is the lack that, in giving up the dimension it hopes to represent (depth) it conspires with the dimension it hopes to please (the line of sight, or "sagittal") to construct the "fourth wall" where the viewer must remain silent and morbid while the drawing speaks on its thin performative stage-space. The silence of the thin drawing is, thus, "rect-ified" in the "verso-surplus," the virt-uality both within and without the physical paper, so that recto and verso reveal themselves to be twins in the classical tradition, that one is human and mortal, the other divine and immortal. ${ }^{3}$ This is not just a parsing of drawing into silent concealing and spoken presentation. It is the necessity of relating recto and verso in a matheme of continual exchange, of making the predicat-ed into the predicate, so to speak.

Reversing predication is what drawings do. This has several senses. If I say "ink is black," it does not hold that "black is ink," but when there is black - in a scene, in the world, in the soul - it is nonetheless true that I reach for my pen. ${ }^{4}$ The absurd flip creates a detached reality, as when all of the Cretans who are liars allow a reversed predication: all liars will have their own country and call it Crete. ${ }^{5}$ The absurdity of such a reversal, the effect that makes the cause, was Vico's way of creating his new science, which for any given side to the drawing surface, paper would have no thickness, no firmitas. Thickness may seem to stand in the way of Platonic 
effect sought as "many causes as possible." ${ }^{6}$ This reverses the billiard-ball entropy to pull all of the ivory spheres out of their pockets to form the impossible-Real constellations that to most would be the end of the evening of billiards, but to the pool-shark Minnesota Fats (Jackie Gleason, The Hustler), whose skill is the palindromic vision that sees in advance the balls in the pockets and calls them to retrace their steps.

Minnesota Fats' divinity as a pool-shark comes from his reversed predication abilities, his famous silence in executing masterful shots. This is his habitus, his "network of dispositions toward doing things in a certain way." His reputation for silence follows Wittgenstein's curious advice in his Tractatus Logico-Philosophicus: "About those things of which one cannot speak, one should remain silent" (Wovon man nicht sprechen kann, darüber muss man schweigen). The moralizing ought seems to be an unnecessary demand. Why would marking off a space lead to a directive, a law? And, why does this 1:1 come about only through a negative, through a silence? Is this reverse predication related to the recto/verso condition of the drawing, the thinness/thickness of its surface? How?

I would like to consider this in light of the relation of the drawing's illusory potential to represent perspectival space. Within this space, I contend, there is a continual active element of orthography - the presence of a section-drawing logic - that translates what is invisible in perspective (the sagittal dimension) as the anxiety that has constructed the sagittal's function of near and far as an instruction to fight or flee (dæmon/ askesis). Privation (remaining silent) converts to the law (orthopsychics, self-correction) that prohibits, like Socrates' dæmon Eros, only by advising inaction. This commands the eye not to be an Icarus who views the scene from above, but to stay close to the ground that sections the scene, in a "true" orthography of touch. "We see that which we would desire and that from which we would flee" saves us as a species from being eaten by allowing us not just to fear and love, but to fear what we love and love what we fear. We create orthography to extend life beyond the point of literal death. In this space "between the two deaths" (Lacan), we won't know that we are dead, we will, like Nabokov's shadow of the waxwing, "slain by the azure in the window-pane," live on, fly on, in that reflected sky. ${ }^{7}$

\section{SMUGGLERS, PICKPOCKETS, DOUBLED BOUNDARIES}

What the living being desires is a little peace and quiet: a circuit where privation (isolation from a buzzing, unpredictable environment) constructs an immediate verso, prohibition. A Law, Kafkaesque though it may be, now rules through misrule, a "Cockaigne or Cockayne, "a land of plenty in medieval myth, an imaginary place of extreme luxury and ease where physical comforts and pleasures are always immediately at hand" (Wikipedia). If imagination ever needed a place to stay, it would be in this Land of Fools, whose isolationist policies convert the folly of the master into wisdom of the servant - a secret that Hegel would give away again so many years later.
Contronyms, palindromes, and reverse predications rectoand-versofy the "spaces inside spaces" and "times inside times" that are the bases of all creations of the imagination. The fool-without-an-education asserts, through double reversal, that education-without-a-fool is a bad idea. So black is back in the ink that would make it a country, a Cockaigne of misrule where everything lies at hand - if only because once you are dead (mortified thanks to entry into the virtuality of the represented world) you should have anything you want. You are "between the two deaths" and it's time to correct (rect-ify) what was wrong with contingent mortality through the fractal geometry of this universally recognized journey, celebrated in all cultures as the spatio-temporal counterpart to the period of mourning that waits for, or actively encourages, the flesh to leave the bone.

Poetry's rectifying verso is rhyme, a sound repetition that allows, in its circuit around to the same sound as meaning changes, the trope executed with a little leap - not too big a leap, just a foolish one. Meditating mystics claiming powers of levitation could not outdo the reported achievements of fools in ancient times. The Middle Ages connected folly in general with the saut ("leap") of the acrobat. With the circuit to frame the work of art comes the little jump: a gapped circle. Going toward the bad and fleeing the good sums up Freud's problem in particularizing the logic of the death drive, which was not really a drive toward death but a sum of all the efforts undertaken, as Lacan put it later, "so that the living being doesn't perish every time it turns around" (Seminar, II). Out of nature into what? - Into the virtuality that sets itself up inside the verso, the turn, the other side of the ink.

Contronyms, terms that conceal oppositions, parallel the practices of smugglers and pickpockets, who must move across boundaries by creating in-between poché spaces to conceal stolen goods. The logic is the same. Between inside and outside, there is a double pocket, where in and out overlap. To describe the functionality of this pocket, we have to connect to several unexpected mythical precedents. The first case is the clearest case, one discovered originally by Vico in his Autobiography. ${ }^{8}$ The word colum, he notes, means both the heaven, mythically present as the skull of the sky-god Zeus, and a wedge. This unlocks the secret of Athena's escape from Zeus's head following a blow from Hephaistos's axe. It explains Athena's relation to the Athenian citadel, a militarized position of defense, surveillance, and authority over the polis. It is a story narrated unconsciously by any drawer who picks up a stylus (burin) and, from a position of artistic detachment, creates a point of entry on the page - vigilant, exclamatory, hoping for mastery.

If it is not too astounding to connect the drawing act to the ritualized access to the Parthenon, we can gain access to the universal logic of any boundary across which secret goods are smuggled alongside normative traffic; indeed, any 
transgression where inside and outside open to conditional passage by means of a double fold that is simultaneously a palindromic fold of space and time.

The burin, like the partridge, stays close to the surface where it lives. This is one side of the contronymic cœlum, whose other sense is heaven. It is thus contronymically inevitable that Hephaistos will split Zeus's skull with an axe. The tool and its object are one. The burin and the image-surface are one. The citadel emerges, the interior point of view where Athena looks out from her inside frame to see and say: surveillance and the Law, two sides of one thing, nomos and polis. The plow-point of the urbs has encircled space like a charm that can be unturned with a curse, by the likes of the Israelites who destroyed Jericho simply by marching in a circle, shofars blaring. The contronymic of blessing and curse is preserved in the ambiguity of hostes, both hospitable and hostile, and the VGHE, which unites guest and ghost. Orthography (= contronymics, "keeping close to the surface") creates orthopsychics (correction, Law).

Graphically marking off a space on paper is not a simple matter. The "Jordan Curve" (the mathematical name for continuous enclosure) is nearly impossible to describe, possibly because enclosing is simultaneously dis-closing: the Lacanian figure of "extimacy," the intimate object. ${ }^{9}$ Cutting off, the privation of encirclement, directly produces prohibition, the Law of Athena, the surveillance and selfcorrection, ortho-psychics, a sense of the whole to "see" (from the citadel) and "say" (give laws) without constructing a remote point of view. ${ }^{10}$ We feel extimacy whenever we desire or fear something within the perspectival field. It squeezes or stretches the sagittal depending on whether we fight or flee. ${ }^{11}$ Stabilizing the visual domain through parallax meroics (the seeming 1:1 quantum exchange between concealing and revealing) puts something into visibility while simultaneously accumulating a trash pile of invisibility. This is also a 1:1 process! The invisible doesn't just go away. It maintains its negativity in a positive formation, a junk-yard of rejections that, thanks to being devalued, are preserved forever. ${ }^{12}$

Can the future of the drawing be described as an "unconscious" that will, like the impish Id, the fool who rules over Freud's trash-heap unconscious, suddenly come forward with its verso account of things? Will the drawing in this sense be a mirror suddenly revealing the identity/authenticity of the one who was first occupying the fourth-wall space in front of the page? Diego Velázquez certainly thought about this when he constructed Las Meninas as a perfect visual palindrome, by offsetting the perspective's main vanishing point only a few centimeters from the vanishing point of the verso painting reflected in the mirror, seen from the back (because it paints "us") as an ortho-psychic "truth of painting."
This was a truth of quantum exchange, of invisibility that would return, part for part, 1 for 1 , out of the dark interior created by the flipped-around canvas, the identity of just who stands in the space in front of it. This identity is not about Filipe and Mariana, whose mirrored royal faces are reflected from the back of the room. It was not about the painter who, in creating Las Meninas, had to stand in the same spot. It was not about the subsequent viewers of the painting who would, in occupying the place of the dead, also acquire their voice (apophrades), a voice that is acousmatically aligned with the corner of the painting that is jointly possessed by two fools and a dog. Here, the corner is like the corner of a page in a book. It is bent (troped) so that the reader may turn it to look quickly (but not quickly enough) to the other side. But, this "other side" is already present. It has been already made present, in the slow accumulation of Invisibles that, thanks to the reversed canvas, the reversing mirror, and the Inverse Beings (the deformed fools and sleeping dog) lie while and where they lie.

They don't lie still. They leap (sauter) and clown about (sots, fools; sotie, fool play). But, they don't jump far. They stay close to the ground, just as the pencil or pen stays close to the paper. There is a surprising connection here. In Antonello da Messina's painting of Saint Jerome in His Study (1460-1475), the painting is enclosed in a double frame. This is a turn, a trick. Every frame is double in that it points "outward" to the visible space of representation and "inward" to the viewer, through the so-called fourth wall, the space of production/ reception co-occupied by the makers (the apparatus, dispositif) and later the audience. In this case, the second frame is turned around to represent - in a way appropriate to a saint - the oculos Dei, the hole in space through which God gazes at Jerome.

The turn-around has thickened the margin so that a few things placed on its lower ledge will have something important to say about representation's authenticity. Initially, they appear to be icons relating to Jerome's thesis about Mary's perpetual virginity: a golden bowl representing a womb that is simultaneously empty and full; a peacock whose uselessness opens the way to the "open semiosis" of Paradise. The third presence is more mysterious. The art historian Penny Jewell has translated: the partridge was a bird so notoriously libidinous that it could be impregnated by the wind..$^{13}$ This suited Jerome, who, as translator of the Vulgate Bible, moved directly from divine inspiration (afflatus, wind) to word, and to word's incarnation into flesh.

The partridge (Perdix) shares its name with Dædalus's nephew, murdered by his jealous uncle for "stealing" secrets from the master. But, this was a reverse predication; it was Dædalus who appropriated his precocious nephew's discoveries and then pushed the too-young genius off a cliff. Since then, Perdix's bird-descendants stay close to the ground. 


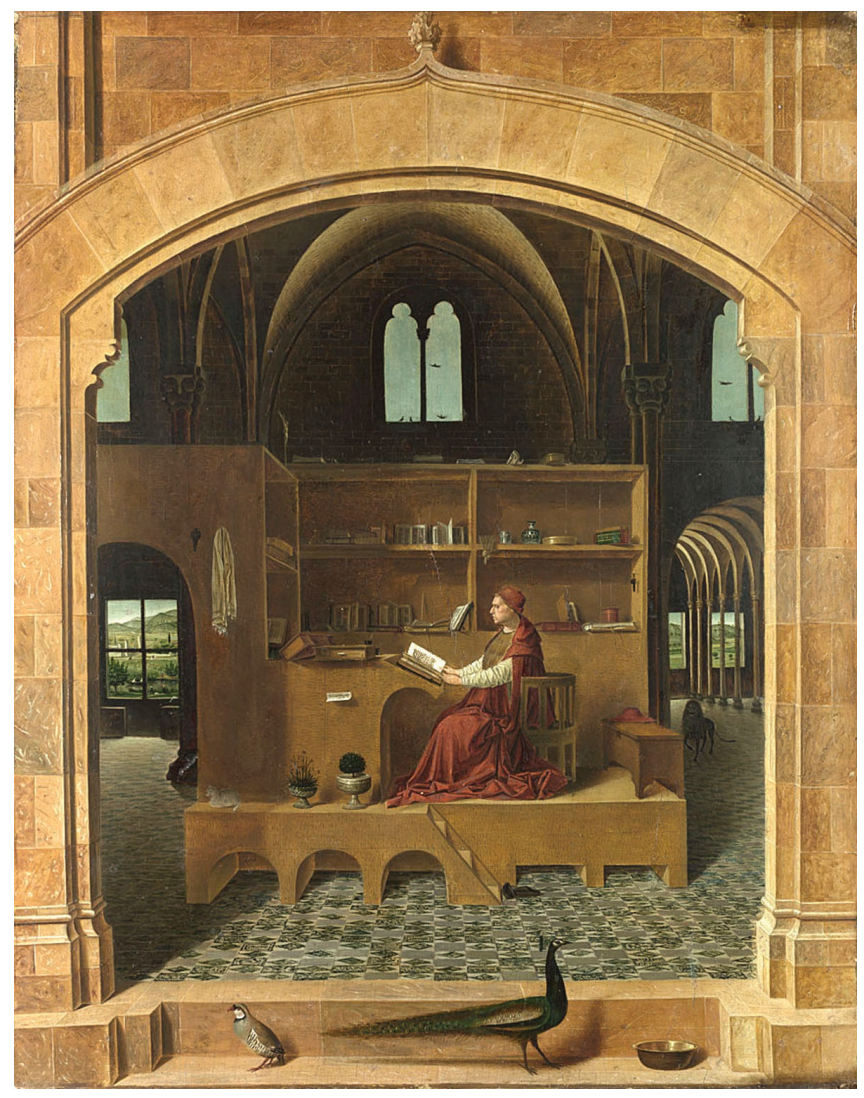

Figure 2. Antonello da Messina, Saint Jerome in His Study, c. 1474-1475, $45.7 \mathrm{~cm} \times 36.2 \mathrm{~cm}$. We see the painting doubly framed, to indicate the oculus by which God looks at Jerome in the act of translating the Vulgate Bible. Objects on the sill (golden bowl, peacock, partridge) constitute a rebus-like puzzle about translation, perpetual virginity, and Jerome's own Prägnanz. Image courtesy of the Trustees, The National Gallery, London.

Isn't this the secret of the pencil, and ink? That they must be close to the paper? But, in keeping to short flights, these instruments also become instrumental in the Medieval sense of this form of causality, which unconsciously transmits truth because it has no will of its own. As the puppet/servant, the line may partake of the magic of the palindrome that, rectoverso style, thickens the page into a Real that is sheer reversal, sheer sotise. The Fool of the Tarot stands on the edge of the cliff, like Perdix; but the "wise fool" (cf. kenosis, "knowing without knowing") does not jump. The black of the line opens up the sight to light. The meroic ${ }^{14}$ (part by part) exchange between visibility and invisibility, lost when parallax breaks down, returns when the trash pile gives back its treasures. Stories told three thousand years ago make sense, just now.

This is not the empirical "now" that is now in the here-andnow sense, the now that is now no matter where it goes. We forget the difference between this now and the memorymade now that is a fantasy construct. This memory-now is re-packaged by looking back. We back up the road to pick up this left-behind now. The problem is that, in backing up, we have inserted a future that the now did not yet know. The real now is the now anxious that it does not know what's next. The anxious now places the now within the perspectival domain, where the sagittal dimension is squeezed and stretched to accommodate our desire to chase or run away. Packaging the now as a memory gains a fantasy at the expense of the traumatic Real of the now, its lack of a future.

Divination liquidates this desire and fear by formalizing a theatrics of fear and desire. To divine is to cast forward, project, a moment "by the time of which" something will have taken place. This traditionally requires pronouns. The Sibyl says that a great army will fall, and the optimistic general cannot believe that it's his army she's talking about. Pronouns open up a generic path that, when filled with specifics, fill us with astonishment. You wait for Prince Charming, but you will be surprised to find out exactly who he is. The logic is the pronoun spectator Velázquez put in front of Las Meninas. The point is not to say who wins the pronoun contest but to realize that it's Everyone, not a single but a singu-larity, a collective that acts as a One.

\section{ORTHOGRAPHICS TO ORTHOPSYCHICS}

A drawing is made by the intimate but also intermittent contact between the paper and a pen, pencil, or burin. The paper is more or less flat. The space directly above the smooth surface is the "apparatus" space, the dispositif in Bachelard's terms. It directly alters the surface, its actions are evident only through a forensic analysis of the strokes or knowledge of the artist's methodology. The relation of the drawing surface with the production space above it is orthographic, a 1:1 exchange. When the drawing is itself representationally orthographic, this 1:1 extends to what is being objectified by the drawing. This may be a façade shown "face-on," whose flatness makes this angle of view useful. ${ }^{15}$ If the flat plane cuts through the material of the building, the solids are cut not in an optical sense but a tangible "surgical" way, as a body is cut in a post mortem anatomy. Voids in the solid are often shown in perspective, as if orthography and perspectivalism were not mutually exclusive. But, orthography relates to a more intensive aspect of perspectival space: the sagittal, where the line of sight fans out to meet objects in the field "as if" in an orthographic confrontation. A viewer with X-ray vision might realize a kind of spherical array of sectioned objects. The sagittal line's orthographic transference to a radial field is in fact what happens in the Panopticon, a circular prison with a central guard tower around which are arrayed "half cells," sectioned with the specific purpose of "cutting into" the physical and psychic space of the prisoners, who cannot tell if at any instant guards are present or absent. ${ }^{16}$

The Panopticon example reveals a particularly interesting aspect of the partridge's "low flight" relationship to orthography. The Panopticon is not just a drawing turned into a building; it is a building that is a drawing, a section drawing. The radial arrangement allows the binary presence/absence of the guard 
tower to penetrate equally each half-cell. It is not the case, as Foucault claimed, that because the prisoners can't tell if guards are present at any given moment, they assume that guards are present all the time. The prisoners assimilate the binary presence/absence directly. The guards are blind in two ways: they can't be seen and, when they are absent, they can't see. Invisibility is coupled with blindness, just as in the orthographic section drawing, the 1:1 position of the "orthographic eye," as Paul Emmons has called it, leaves its position as an "eye" at a central point of view (becoming blind, giving way to touch) just as it is the invisible dispositif making possible the total "candor" of the materials cut by the section plane. ${ }^{17}$

The orthographic cut creates two surfaces from one, every part of which is "locked" into a 1:1 relationship. The invisible orthographic eye, being blind as well, nonetheless penetrates the shell of the material building. While the view of the whole as a unified spectacle is lost with the abandonment of the single point of view, what is gained is a "meroic" part-by-part array. This is significant in relation to a different kind of meaning of drawing - what I shall call a "quantum" meaning in that the exchange of visibility and invisibility presumes a limited commodity of each. The two conditions exhaust all possibilities, so that there is nothing that is not either visible or invisible. But, there is an interesting third condition that arises. Because of their complementarity, quanta of the invisible exchange with quanta of the visible in a 1:1 manner. The orthographic eye must leave one position to take up another. Its motion mandates the 1:1 quantum relationship.

At the same time, visibility and invisibility have a parallel palindromic relation reinforced by this leaving/arriving motion of the orthographic eye. While the mode of partial display refuses the perspective of a single point of view "flying high," like Icarus, above the drawing surface, its partridge-like shuffle along the drawing surface aims at a quantum authenticity. In fact, the quantum exchange focuses precisely on the issue of authenticity.

In an ancient but identical consideration of the authenticity of the meroic, "the paradox of the Ship of Theseus" wonders at what point the hero Theseus's historic ship, which the Athenians kept in repair by continual replacement of broken/rotted parts, was still the Ship of Theseus. When $100 \%$ of the ship's parts have been replaced, it would seem that although Formal Cause's concerns have been met, Material Cause would answer no. Yet, there seems another approach. When Heraclitus asserted (allegedly) that you cannot step into the same river twice, the situation might be expressed differently. "If you think you are stepping into a river twice, call it something else." The question is about the meaning of the same. What is the same in the orthographic procedure is the $1: 1$ quantum replacement of invisibility by visibility. This converts to an ortho-psychic authenticity. Just like the Panopticon, blindness converts to touch and touch converts to a penetrating vision that sees both sides of the paper by means of the dispositif's X-ray vision.
The same, the identity of the self in the face of radical changes - not just of living one's life but of discovering one's inescapable Jekyll/Hyde nature - forces us to locate the point of view that defines a view (privation) and simultaneously gives a law (prohibition) at the "nowhere/everywhere" of orthography. In drawing a perspective scene, we construct a section drawing at the same time; our perdix-eye scoots, following the burin's motion, across the surface of the page. The pile of fragments produced and collected "soretically" accumulates an unconscious, just as Velázquez discovered that blobs of paint would accumulate color in a way that necessitated a transfer of synthesis to the eye of the viewer. The interior would be the anterior, the painting would "happen" at the future anterior moment of reception, the building's venustas would be the result of a meroic 1:1 movement within firmitas. The use (utilitas) would reside in the construction of perspectival anxiety, the space of the sagittal, the fight or fright. The center (burin/colum/ortho-eye) will be everywhere (perdix) and - as the impossibly distant POV - nowhere. Wovon man nicht sprechen kann, darüber muss man schweigen.

\section{ENDNOTES}

1 Giambattista Vico, The New Science of Giambattista Vico, trans., Thomas Goddard Bergin and Max Harold Fisch (Ithaca, NY: Cornell University Press, 1975), §§ 36, 145, 162, 445, 482, 527, 542.

2 The controversy of Oresteia was that the Athenian playwright had "unthinkingly" revealed secrets of the Eleusinian mysteries, thinking them not in terms of ritual practices but of common experiences that are innately revelational, but whose understanding at a deeper level will be present only when communicated to those who have shared in their paradox. Marcel Widzisz, "The Duration of Darkness and the Light of Eleusis in the Prologue of Agamemnon and the Third Stasimon of Choephoroi," Greek, Roman, and Byzantine Studies 50 (2010): 461-489.

3 The dioscuri were, as "sons of Zeus," were not just Castor and Pollux. ( $\Delta$ เóokoupoı Dióskouroi, "sons of Zeus," from Dîos, "Zeus," and Koûroi.) Sons of a god in that only divine (divus, in the sense of the addressee of divination) cause can render the clairvoyant effects produced by two opposed cyclic "forces" circu-lating through a set of meridians that allow them to exchange places between life and death, visibility and invisibility, here and elsewhere, without requiring anything more than their own contronymic logic, making them in effect heroes of the recto/verso. The fate of the famous Dioscuri, Castor and Pollux, was cosmically geometrical. The twins would occupy 180 positions of a cycle, rotating between the half-realms of life and death. As one twin was "born" in the movement from death to life, the other would "die" in an opposite motion. The companionship Hades had grudgingly allowed them was radically detached but some say that on special occasions they were allowed to pass along the meridian line separating them. It seems that they may have done so to save the life of Simonides in gratitude for his inclusion of passages of praise for them at the banquet of Scopus, a wrestler celebrating his recent victory by pitching himself a setesis. Simonides had devoted half of the encomium to the twin gods, thinking it appropriate - after all, the Dioscuri were the patrons of athletes and especially wrestlers. Scopas however scolded Simonides and refused to pay half the fee. Midway through the banquet, Simonides got word that "two men" wished to speak with him outside, but when he went out to meet the street was empty. Before he could re-enter, the banquet hall collapsed, crushing all inside. His art of memory allowed him to identify the crushed corpses by means of their positions, and the relatives grateful to be able to give their fathers proper burials more than compensated Simonides for his skill.

4 The connection between drawing and melancholia was established by Albrecht Dürer in his famous "Melencolia §I," according to the analysis of the quantum physicist, David Finkelstein, The Melencolia Manifesto (San Rafael, CA: Morgan \& Claypool Publishers, 2017). Dürer not only created a misspelled "melencolia" to produce the anagram, limen coeli, but his polyhedron reveals that a true cube (in the sense of a hypercube) is revealed as a cube falling/rising through a planar surface.

5 In present-day Crete, as in ancient times, there is a custom that, to become a man, one must steal a sheep and then lie about it, first in a denial made to the owner but then subsequently through a series of formalized judicial reviews where the form of the lie undergoes successive transformations, until at last, the circle of denials fulfills the ritual requirements constituting a confession of the crime. Source: personal conversation, Prof. Evangelos Kyriakidis, FSA, Senior Lecturer in Aegean Prehistory, Kent University, Elefsina, Greece. 
6 Giambattista Vico, On the Study Methods of Our Time (1704), trans., Elio Gianturco (Ithaca, NY: Cornell University, 1994)

7 Vladimir Nabokov, Pale Fire (London; New York: Penguin Books, 2016; 1962). The first lines of the poem written by the novel's fictional poet, John Shade, disclose the secrets of reversed predication: "I was the shadow of the waxwing slain / By the false azure in the windowpane; / I was the smudge of ashen fluff - and I / Lived on, flew on, in the reflected sky." Nabokov unintentionally states the precise formula of Freud's death drive, as the sum total of efforts of the human organism to avoid extinction by creating an artificial circuit of self-sustaining internalized stimulation, based on "gratuitous" divisions, such as that made by the poem's protagonist, Kinbote, who steals Shade's poem and annotates it to demonstrate that, in fact, the poem is about his (delusional) past as the exiled King of Zembla. The accidental flight of the bird into the reflection of sky in the window that will kill it is the Lacanian "first death," to be followed by an interval of kenosis. The bird does not know that it knows that it is dead, yet this knowledge operates as an internal corrective algorithm, curving the story into a perfect round (privation) punctuated by the gap, where death ${ }_{1}$ confronts a corrective/psychic death . $_{2}$

8 Giambattista Vico, The Autobiography of Giambattista Vico, trans., Thomas Goddard Bergin and Max Harold Fisch (London: Cornell University Press, 1995), 218.

9 Lacan's topological interests led him to condense many psychoanalytical issues into the figure whose interior was simultaneously an exterior. The primary intention, to identify an "intimate exteriority," produced a complementary "alien interiority," a void at the center of the subject. This inversion was related to other, seemingly non-topological binaries, such as the distinction between énoncé (the content of speech) and énonciation (the act of speaking). As the word content suggests, the conscious meaning of speech is an interior framed by rhetoric, context, gesture, etc. The act however occurs in a public space that contains and contextualizes this frame. Jacques-Alain Miller, "Extimity," Symptom 9. http://www.lacan.com/symptom/extimity.html.

10 The expression "see and say" conveys the Athenian paradox of the citadel, a place that is a breach, look-out, and place of authority. Not accidentally, it corresponds to Lacan's distinction between content (énoncé) and speech act (énonciation). The mathematician John Conway has discovered a mathematical correlate to this distinction. The bipolar universal exemplified by the Cretan Liar Paradox has, in mathematics, an analogous constant value (the Conway Constant), which grounds the sequence of numbers produced by saying what one sees in a printed number. With " 1 " we see a number one and say what we see: "one 1 ," which we write as 11 . Then we see two 1 's, or 21 . Then, we continue the process by writing 12 and 11, or 1211; then, for this number, 111221, and so on. This sequence has its Conway Constant, but something significant happens in the case of the palindromic sequences. If we take the last line of Cantor's single-numeric triangle of transfinite numbers, $1 / 9,2 / 8,3 / 7,4 / 6,5 / 5,6 / 4$,

$7 / 3,8 / 2,9 / 1$, and treat it as a look-and-say sequence, the numbers produce a pyramidal "pile," with a base of nine 1's topped by one 9 . Any triangular part of this pyramidal pile works like a hologram part that converts to the logic of the whole, through a look-and-say conversion, back to a line in Cantor's series of transfinites. 111, 22, 3 for example becomes 1/3, 2/2, 3/1, the third "line" of Cantor's series. See "Look and Say Sequence," Wikipedia. https://en.wikipedia. org/wiki/Look-and-say_sequence.

11 A striking visual example of this is given in a well-known scene from Alfred Hitchcock's 1958 film, Vertigo. When the ex-detective Scottie, who (like the partridge) has a fear of heights, attempts to climb the convent bell tower, he glances at the ground and the camera simultaneously changes its focal length and position to produce the uncanny effect of a space that is both stretched and compressed. This is the fear of vertigo: that the fall will be greater than it is but that the threat is closer than it is. This <> is the marker of the extimate, the poinçon that Lacan uses to define desire in his matheme, $\$ \diamond a$, read as "the barred subject in an authenticated relationship with jouissance." Scottie is certainly barred by his relationship to Judy, who had masqueraded as Madeleine. $\$ 0 \mathrm{~J} / \mathrm{M}$ is Vertigo's matheme, where we see the film itself as a Jordan Curve privation that simultaneously constructs an ortho-psychism in the form of Scottie's desire to "correct" Judy back into her impossible/Real double, Madeleine. As the actual wife of Elster, who murders her for her money, Madeleine fills the bill by "not existing" only for Scottie: the perfect object of desire.

12 This discard pile was Freud's inspiration for the idea of the unconscious. Giovanni Morelli (Ivan Lermontief) discovered a method for authenticating paintings: look at the parts that the painter doesn't care about - the fingernails, the ear-lobes, the aureoles - to see the artists fingerprints most clearly. Freud then realized that the unconscious, which cannot exercise the powers of negation, accepts everything into its garbage dump; but that its order is that of the sorites that suddenly acts within an instant of the Real to confess a retroactive/palindromic logic, written in the future anterior of "by the time of which, this will be complete" (Wo Es war, soll Ich werden). Carlo Ginzburg and Anna Davin, "Morelli, Freud and Sherlock Holmes: Clues and Scientific Method," History Workshop 9 (Spring 1980): 5-36.

13 Pennyc Howell Jolly, “Antonello da Messina's Saint Jerome in His Study: An Iconographic Analysis," The Art Bulletin 65, no. 2 (June 1983): 238-253.

14 I use the adjective form of "meroism" (from the Greek $\mu \varepsilon$ pos, part) to indicate a unit that is a division in relation to an implied whole, fictional or real. A meroism is the combination of two contrasting words to refer to an entirety. I extend this to see, in any one word or idea, a virtual complement that does the same thing.
15 The flatness of the paper is not exactly a simple matter. In Euclidean terms, flatness relates to the extended line, shortest distance between two points. But, on earth or any other planet, flatness is correlated to the arc whose points are equidistant from the center. Paper is, essentially, a contronym combining the idea of flatness and curvature.

16 See Joan Copjec, "The Orthopsychic Subject: Film Theory and the Reception of Lacan," October 49 (Summer 1989): 53-81. Copjec productively identified Gaston Bachelard as the proper author of the idea of dispositif but she failed to complete her correction of Michel Foucault in his application of this idea to the Panopticon, Jeremy Bentham's ideal prison design. Foucault had it that, because the prisoners couldn't tell when the guards were in their watch-tower, they assumed that they were always present. But, prisoners were fully able to realize, as a "subjective universal," the contronym presence/absence. Instead of attributing absolute invisible power to the tower, they were interpellated by the defect in the Other (the guards) - a defect more powerful than any unified "flat" representation. Had Copjec pursued this critique, she would have been able to show how the relation of dispositif to the orthography of the prison building (which embodies the idea of the section drawing) reveals the necessary relation of orthographics to orthopsychics - the "self-surveillance" that Bachelard saw positively, as a means of breaking free from history.

17 Paul Emmons, "Phenomenology and the Architect's Orthographic Eye," in A Carefully Folded Ham Sandwich: Towards a Critical Phenomenlogy, ed., Roger Conah (Montreal: Fàd Design House, 2013), 51-71. The author wishes to thank Emmons for his inspiration and critical guidance on this topic. His poetic ophthalmology of the orthographic eye has opened up an original and promising line of research that will benefit generations of scholars in the future. 